\title{
COAGULATION ABNORMALITIES IN ISCHAEMIC OPTIC NEUROPATHY
}

\author{
J. F. ACHESON and M. D. SANDERS \\ London
}

\begin{abstract}
SUMMARY
The aetiology of non-arteritic ischaemic optic neuropathy (ION) is multifactorial with local anatomical and systemic haemodynamic abnormalities both playing a role. A careful search for treatable vascular disease risk factors is required to allow rational therapy, to optimise the visual prognosis and to allow new insights into pathogenesis. We describe 7 cases in which there was an associated thrombophilic (prothrombotic) state; 4 had deficiencies of the physiological anticoagulants proteins C and S and antithrombin III and 2 had anti-phospholipid antibody (lupus anticoagulant) syndromes. A further patient had reduced levels of the physiological fibrinolytic agent tissue plasminogen activator ( $t$-PA). In 5 patients other risk factors for small vessel occlusive disease were also present, and $4 \mathrm{had}$ recurrent episodes of ION in the same eye. The visual prognosis in these patients may be improved by anticoagulation with warfarin.
\end{abstract}

Ischaemic optic neuropathy (ION) is currently divided into two categories: arteritic, generally due to giant cell arteritis and occurring in the elderly; and non-arteritic, occurring in a younger age group. It is generally held that vascular insufficiency in branches of the short posterior ciliary vessels supplying the retrolaminar optic nerve is a central factor in the pathogenesis of non-arteritic ION. ${ }^{1-5}$ Rheological abnormalities are frequently identified. These include the three components making up Virchow's triad for conditions predisposing to thrombosis: disorders of the vessel wall (arteriosclerosis, diabetes, hypertension, migraine), disorders of blood flow (haemodynamic shock, emboli, carotid artery occlusion) and disorders of blood constituents (hyperviscosity) ${ }^{6}$ In addition, there may be evidence of an anatomical predisposition as small optic discs with low cup-disc ratios are especially vulnerable, ${ }^{7}$ and buried optic disc drusen may also contribute a risk factor. $^{8}$

Correspondence to: Mr J. F. Acheson, Department of NeuroOphthalmology, National Hospital for Neurology and Neurosurgery, Queen Square, London WCIN 3BG, UK. Fax: 071-829 8720.
In the context of cerebral ischaemic disease it is now becoming apparent that primary abnormalities of the haemostatic mechanisms (both hereditary and acquired) may also result in unchecked thrombus formation. These thrombophilic or prothrombotic disorders include defects in the physiological anticoagulants antithrombin III, protein $\mathrm{C}$ and protein $\mathrm{S}$; defects in normal fibrinolytic mechanisms; and the presence of anti-phospholipid antibodies. $^{9.10}$ We have therefore studied a group of patients with non-arteritic ION to look for underlying thrombophilic states and to assess their possible significance.

\section{METHOD}

Since January 1992 all patients attending the Neuro-Ophthalmology Clinic at The National Hospital for Neurology and Neurosurgery with a diagnosis of non-arteritic ischaemic optic neuropathy (ION) underwent a detailed search for possible abnormalities of thrombosis and haemostasis. This followed initial measurement of blood pressure, haematocrit, plasma proteins, lipids and cholesterol, glucose, and erythrocyte sedimentation rate, together with the recording of any history of venous or arterial thrombosis elsewhere than in the eye, smoking, circulatory collapse, migraine, Raynaud's phenomenon or other vascular disease. Specific tests to exclude other causes of an optic neuropathy including compression, demyelination, granulomatous infiltration and Leber's hereditary optic neuropathy were performed as appropriate.

The assessment of thrombosis and haemostasis included: full blood count; standard clotting screen of INR (International Normalised Ratio) or PT (prothrombin time) and APTT (activated partial thromboplastin time); lupus anticoagulant screen by dilute Russell viper venom test (RVVT); anti-cardiolipin antibodies; fibrinogen; factor VIII; von Willebrand's factor; protein C; protein S; antithrombin III; t-PA (tissue plasminogen activator); PAI (plasminogen activator inhibitor); platelet aggregation assay.

\section{RESULTS}

The results are summarised in Table I. Two patients had 
Table I. Summary of results

\begin{tabular}{lcll}
\hline Case & Age and sex & \multicolumn{1}{c}{ Thrombophilic state } & \multicolumn{1}{c}{ Clinical details } \\
\hline 1 & $29 \mathrm{~F}$ & Protein C deficiency: 71.1 u/dl (normal 82-146) & $\begin{array}{l}\text { Bilateral recurrent ION. Transient post-partum } \\
\text { antiphospholipid antibodies } \\
\text { Bilateral recurrent ION. Diabetes, raised } \\
\text { fibrinogen, hypertension }\end{array}$ \\
2 & $49 \mathrm{M}$ & Lupus anticoagulant: DRVVT (ratio) 1.3 (normal 0.9-1.1) & $\begin{array}{l}\text { Bilateral recurrent ION. Cigarette smoker } \\
\text { Unilateral non-recurrent ION. Family history vascular } \\
\text { disease. Cigarette smoker } \\
\text { Bilateral recurrent ION. Perioperative visual loss at initial } \\
\text { episode } \\
\text { Bilateral non-recurrent ION. Hypertension controlled with } \\
\text { captopril } \\
\text { Bilateral non-recurrent ION }\end{array}$ \\
5 & $28 \mathrm{~F}$ & $\begin{array}{l}\text { Protein C deficiency: 75.3 u/dl (normal 82-146) } \\
\text { Protein S deficiency: 60 iu/dl (normal 63-124) }\end{array}$ & $\begin{array}{l}\text { Free antigen: 22 iu/dl (normal 28-72) } \\
\text { Lupus anticoagulant: DRVVT (ratio) 1.35 (normal 0.9-1.1) }\end{array}$ \\
\hline
\end{tabular}

reduced levels of protein $\mathrm{C}$, one of protein $\mathrm{S}$, one of antithrombin III and one of tissue-plasminogen activator $(\mathrm{t}-$ PA). A further 2 were found to have the lupus anticoagulant. There was bilateral involvement in 6 of 7 patients, and recurrent or progressive episodes of visual loss in the same eye in 4 of 7 . In addition, 2 patients presented before the age of 30 years.

\section{DISCUSSION}

In a typical attack on ION there is painless, fairly sudden visual loss with pallid optic disc swelling, and arcuate or altitudinal field defects. ${ }^{1,2}$ Second eye involvement is said to occur in up to $40 \%$ of patients and recurrent attacks in the same eye, although infrequent, are also described..$^{11,12}$ In this group of patients there was bilateral involvement in 6 of 7 and recurrent or progressive episodes in the same eye in 4 of 7 . In addition, 2 patients presented before the age of 30 years, which is highly unusual. In previous reports of ION in young adults ${ }^{13,14}$ an underlying cause either has not been found or has been attributed to migraine. ${ }^{15}$

All patients typically had small optic discs but none had evidence of optic disc drusen. All patients had been correctly diagnosed before referral and had been treated appropriately by optimal control of standard vascular disease risk factors and by taking aspirin daily. However, 6 went on to develop successive episodes of visual loss prompting the further search for underlying circulatory abnormalities.

\section{Inherited Thrombophilia}

The haemostatic balance is maintained by complex interactions between the coagulation system, physiological anticoagulants, the fibrinolytic system, platelets and the vessel wall. The coagulation cascade is undergoing constant low-grade activity to produce small amounts of thrombin. Physiological anticoagulants such as antithrombin III and the protein C and S system oppose this generation of thrombin by inactivating activated coagulation factors. Specifically, once activated by a complex interaction between thrombin and an endothelial surface receptor thrombomodulin, the protein $\mathrm{C}$ system will inactivate factors VIIa and Va. Protein $\mathrm{S}$ and antithrombin
III are required as co-factors. Inherited and acquired deficiencies of the physiological anticoagulants therefore result in a prothrombotic (thrombophilic) state., ${ }^{9,10}$

The association between familial deficiency of antithrombin III and thromboembolism was first recognised in 1965. Deficiency is inherited in autosomal dominant fashion with a prevalence estimated between 1 in 2000 and 1 in 40000 in different series. Such a deficiency is said to account for $2-5 \%$ of episodes of thromboembolism in adults presenting below the age of 45 years. Familial deficiencies of proteins $\mathrm{C}$ and $\mathrm{S}$ were first described in 1981 and 1984 respectively. Two forms appear to exist: lifethreatening homozygous states presenting in infancy with purpura fulminans and skin necrosis, and clinically silent heterozygous states. Protein $\mathrm{C}$ deficiency may have a prevalence of up to 1 in 200 but the rate for symptomatic deficiency may be as low as 1 in 36000 . The true contribution of such mild thrombophilic (prothrombotic) states to vascular occlusive disease can only be established with adequate population studies which are currently awaited. However, it is thought that such states will increase the risk of thrombosis when other risk factors such as malignancy, pregnancy, smoking and diabetes are also present. There are now a number of reports in the neurological literature describing the association of deficiencies of antithrombin III, ${ }^{16,17}$ protein $\mathrm{C}^{18-22}$ and protein $\mathrm{S}^{23,24}$ with ischaemic stroke, with branch retinal artery occlusions and amaurosis fugax.

In this study, cases 1, 3, 4 and 7 had deficiencies of these physiological anticoagulants and case 6 had a related deficiency of the fibrinolytic agent tissue plasminogen activator (t-PA). It is important to note that the abnormal levels which are reported in all the cases in this series do not lie far outside the normal ranges. However, the levels lie more than 2 SD from the mean for our laboratory using healthy controls and we believe them to be significant in the context of a multifactorial disease model. Many of the patients reported here had other risk factors for small vessel occlusive disease, including patient 1 who was positive for anti-cardiolipin antibodies at the onset of visual symptoms but who then became negative for this risk factor. The common risk factors for non-arteritic ION are well known and management is normally directed 
towards treating associated hypertension, diabetes, hyperlipidaemia and increased plasma viscosity. One implication of these data is that there may be a subgroup of patients who in addition to this approach will require formal anticoagulation with warfarin. In 4 of these cases there were recurrent episodes of ION even after the initial diagnosis had been made and therapy started. Recurrent ION in the same eye is relatively unusual and it may be possible to suggest that this feature in particular might justify the search for these subtle abnormalities of thrombosis and haemostasis regulation.

\section{Anti-phospholipid Antibodies}

In recent years a strong association has become apparent between thrombosis and the presence of antibodies to negatively charged phospholipids. Anti-phospholipid antibodies may be found in patients who have systemic lupus erythematosis, syphilis, previous infections and in the primary antiphospholipid antibody syndrome. Antiphospholipid antibodies are a group of autoantibodies which are detected by precipitation or complement fixation texts currently used in standard tests for syphilis, by the lupus anticoagulant test or by solid phase radioimmunoassay for anti-cardiolipin antibodies. Collectively, they all have similar specificity and although in vitro have an anticoagulant effect by reacting with the phospholipid component of the prothrombin converter complex in the coagulation cascade to prolong the activated partial thromboplastin time (APTT), the dilute Russel viper venom time (DRVVT) and the prothrombin time (PT), in vivo there is a paradoxical prothrombotic effect. This is because of further actions on phospholipid components of platelet membranes, on vascular endothelium and on thrombolytic factors including local prostacyclin, antithrombin III and protein $\mathrm{C}$ activation. ${ }^{25.26}$ Neurological and retinal vascular occlusions have all been described in association with anti-phospholipid antibodies. These include central and branch retinal artery and vein occlusions, ischaemic optic neuropathy, amaurosis fugax and cerebral infarction. ${ }^{27-35}$ Long-term anticoagulation may be indicated. ${ }^{9}$

In this series, cases 2 and 5 had the lupus anticoagulant as detected by an abnormal DRVVT. Although both had other risk factors for ION, both had gone on to develop recurrent bilateral disease. There was no evidence of systemic lupus erythematosis or syphilis and both were treated with long-term anticoagulation. In addition, case 1 had both protein $\mathrm{C}$ deficiency and a transient puerperal episode of anti-phospholipid antibody syndrome and it is possible that both factors acted to trigger the initial thrombotic episode.

\section{CONCLUSION}

The pathogenesis of non-arteritic ION is multifactorial. This study suggests that an additional contribution to this multifactorial model may lie in intrinsic disorders of the regulation of coagulation in some patients. Recurrent episodes of ION in same eye raises the intriguing possibility of venous rather than arterial thrombosis in some of these patients. This is currently under investigation, as is the possible role of long-term anticoagulation with warfarin in their management.

The authors are grateful to the following for their referrals: Professor J. Newsom-Davis, FRCP; Mr C. Canning, FRCOphth; Dr E. M. Graham, FRCOphth; and Mr G. Munson, FRCOphth. Dr B. J. Hunt, MRCP, MRCPath, The Haemophilia Centre, St Thomas' Hospital, London, kindly undertook the thrombosis and haemostasis studies.

Key words: Ischaemic optic neuropathy, Prothrombotic disorders, Thrombophilic disorders.

\section{REFERENCES}

1. Boghen DR, Glaser JS. Ischaemic optic neuropathy: the clinical profile and natural history. Brain 1975;98:689-708.

2. Eagling EM, Sanders MD, Miller SJ. Ischaemic papillopathy. Br J Ophthalmol 1974;58:990-1008.

3. Henkind P, Charles NC, Pearson J. Histopathology of ischaemic optic neuropathy. Am J Ophthalmol 1970;69: 78-90.

4. McLeod D, Marshall J, Kohner EM. Role of axoplasmic transport in the pathophysiology of ischaemic disc swelling. Br J Ophthalmol 1980;64:247-61.

5. Hayreh SS. Acute ischaemic optic neuropathy. I. Terminology and pathogenesis. Br J Ophthalmol 1974;58:955-63.

6. Hayreh SS. Anterior ischaemic optic neuropathy. VIII. Clinical features and pathogenesis of post-haemorrhagic amaurosis. Ophthalmology 1987;94:1488-502.

7. Beck RW, Servais GE, Hayreh SS. Acute ischaemic optic neuropathy. IX. Cup-disc ratio and its role in the pathogenesis of acute ischaemic optic neuropathy. Ophthalmology 1987;94:1503-8.

8. Beck RW, Corbett JJ, Thompson HS, Sergott RC. Decreased visual acuity from optic disc drusen. Arch Ophthalmol 1985;103:1155-9.

9. Greaves M. Coagulation abnormalities and cerebral infarction. J Neurol Neurosurg Psychiatry 1993;56:433-9.

10. The British Committee for Standards in Haematology. Guidelines on the investigation and management of thrombophilia. J Clin Pathol 1990;43:703-9.

11. Ernerudh J, Olsson JE, Schench H von. Antithrombin III deficiency in ischaemic stroke. Stroke 1990;21:967.

12. Beri M, Klugman MR, Kohler JA, Hayreh SS. Acute ischaemic optic neuropathy. VII. Incidence of bilaterality and various influencing factors. Ophthalmology 1987;94: 1020-8.

13. Lavin PJM, Ellenberger C. Recurrent ischaemic optic neuropathy. J Clin Neuro-Ophthalmol 1983;3:193-8.

14. Dutton JJ, Burde RM. Acute ischaemic optic neuropathy of the young. J Clin Neuro-Ophthalmol 1983;3:137-46.

15. McDonald WI, Sanders MD. Migraine complicated by ischaemic papillopathy. Lancet 1971;2:521-3.

16. Donnet A, Khalil R, Terrier G, Koeppel M-C, Niee BT, Aillaud M-F. Cerebral infarction, livedo reticularis and familial deficiency in antithrombin III. Stroke 1992;23:611-2.

17. Clouse LH, Comp PC. The regulaton of hemostasis: the protein C system. N Engl J Med 1986;314:1298-303.

18. Kohler J, Kasper J, Witt I, von-Reutern GM. Ischaemic stroke due to protein C deficiency. Stroke 1990;21:1077-80.

19. Matsushita K, Kuriyama Y, Sawada T, Uchida K. Cerebral infarction associated with protein C deficiency. Stroke 1992; 23:108-11.

20. Martinez HR, Rangel Guerra RA, Marfil LJ. Ischaemic stroke due to deficiency of coagulation inhibitors: report of 10 young adults. Stroke 1993;24:19-25.

21. Nelson ME, Talbot JF, Preston FE. Recurrent multiple 
branch retinal artery occlusions in a patient with protein $\mathrm{C}$ deficiency. Graefes Arch Clin Exp Ophthalmol 1989;227: 443-7.

22. Smith DB, Ens GE. Protein C deficiency: a cause for amaurosis fugax? J Neurol Neurosurg Psychiatry 1987;51:361-2.

23. Sie P, Boneu B, Bierme R, Wiesel ML, Grumebaum L, Cazenave JP. Arterial thrombosis and protein S deficiency. Thrombos Haemostas 1989;61:144-7.

24. Davous P, Horellou M, Conard J, Levine WC. Cerebral infarction and familial protein S deficiency. Stroke 1990;21: 1760-1.

25. Hughes GRV, Asherson RA, Khamashita MA. Antiphosphopilid syndrome: linking many specialities. Ann Rheum Dis 1989;48:355-6.

26. Mackworth-Young CG, Loizou S, Walport MJ. Primary antiphospholipid antibody syndrome: features of patients with raised anticardiolipin antibodies and no other disorder. Ann Rheum Dis 1989;48:362-7.

27. Ogino S, Iwamoto K, Yamamoto H, Yamaguchi K, Kondo M. A case of optic neuritis associated with anticardiolipin antibodies. Rinsho-Shinkeigaku 1992;32:330-2.

28. Levine SR, Crofts JW, Lesser GR, Floberg J, Welch KMA. Visual symptom associated with the presence of a lupus anticoagulant (lupus anticoagulant retinopathy). Ophthalmology 1988;95:686-92.
29. Kleiner RC, Najarian LV, Schatten S, Jabs DA, Patz A Kaplan HJ. Vaso-occlusive retinopathy associated with antiphospholipid antibodies (lupus anticoagulant retinopathy). Ophthalmology 1989;96:896-904.

30. Watts MT, Greaves M, Clearkin LG, Malia RG, Cooper SM. Antiphospholipid antibodies and ischaemic optic neuropathy. Lancet 1990;335:613-4.

31. Briley DP, Coull BM, Goodnight SH. Neurological disease associated with antiphospholipid antibodies. Ann Neurol $1989 ; 25: 228-32$.

32. Digre KB, Durcan FJ, Branch DW, Jacobson DM, Varner MW, Baringer JR. Amaurosis fugax associated with antiphospholipid antibodies. Ann Neurol 1989;25:228-32.

33. Jonas J, Koble K, Volcker HE, Kaiden JR. Central retinal artery occlusion in Sneddon's disease associated with antiphospholipid antibodies. Am J Ophthalmol 1986;102: 37-40.

34. Acheson JF, Gregson RC, Merry P, Schulenburg WE. Vasoocclusive retinopathy in the primary antiphospholipid antibody syndrome. Eye 1991;5:48-55.

35. Asherson RA, Merry P, Acheson JF, Harris EN, Jabs DA, Hughes GRV. Antiphospholipid antibodies: a risk factor for occlusive ocular vascular disease. Ann Rheum Dis 1989;48: 358-61. 